\title{
Constituting Precautions and Evasions among Common Individuals from COVID- 19: An Overview from Bangladesh
}

\author{
Kazi Sultana Farhana Azam \\ Department of Computer Science \& Engineering \\ Primeasia University, Banani \\ Bangladesh
}

\author{
Farhin Farhad Riya \\ Department of Computer Science \& Engineering \\ Primeasia University, Banani \\ Bangladesh
}

\begin{abstract}
The flare-up of Covid-19, a coronavirus-caused ailment that started in Wuhan, China, and has since spread to most of the world, is one of the foremost genuine open wellbeing emergencies in decades. Pandemics happen when an unused infection emerges to contaminate individuals and can spread between individuals reasonably. It spreads worldwide since there's small to no pre-existing resistance against the modern infection. The infection that causes COVID-19 is tainting individuals and from person-to-person it is spreading effectively. At this time worldwide endeavors are centered in parallel for reducing the spread and affect from this infection. The associated government is working to reply to this open prosperity hazard with neighborhood, territorial assistants and tribal, as well as open prosperity accessories. Safety measures for this ongoing circumstance can be assigned only if one could be an inhabitant in a denomination where there's continuous spread of COVID-19 and he/she create COVID-19 indications, call their healthcare suppliers and share all the approximate symptoms. At that point they will select whether they need to be attempted or not, but getting to any past address there is no treatment for COVID-19. All the people should be concerned about that individuals who are gently ill are able to separate at domestic. Otherwise all of them will have to go up against many obstructions on their recovery, on the off chance that they have been from any impacted locale or uncovered to someone wiped out with COVID-19 inside the past 14 days. All the casualties from "COVID-19" got to be taken after illuminating in the midst of this time. Everyone's interest is fundamental to the persistent common prosperity response to attempt to direct spreading of this infection.
\end{abstract}

\section{Keywords}

Virus Issue, COVID-19, Data Analysis, Data Graph, Bangladesh

\section{INTRODUCTION}

Inside the past century, four pandemics have been caused by the advancement of novel flu contaminations. Concurring to Nature, the spreading of corona infection contamination 2019 (COVID19) is getting to be persistent and has as of presently come to the imperative criteria for it to be articulated a far reaching, having sullied more than $182 \mathrm{k}$ people in 162 nations as of March 17, 2020, 04:13 GMT [1]. Usually the primary widespread known to be caused by the development of modern corona virus. In this way, an encouraged around the world response is quickly required to arrange prosperity systems to meet this unprecedented challenge. A widespread may be a global outbreak of illness. Uniformity broadcast is being recognized in a creating number of nations and cases that have been distinguished in most of the countries around the world. Countries that have been loathsome adequate to have been revealed to this disease as of presently have, inconceivably, especially beneficial guides to pass on. In showing disdain towards the reality, the control measures actualized in China which have overthrown advanced cases by more at that point $90 \%$, this reducing is not the case in other countries, checking Iran and Italy [2].

\section{LITERATURE REVIEW}

$\mathrm{CDC}$ is reacting to an episode of respiratory infection caused by a novel (modern) coronavirus that was to begin with identified in China and which has presently been recognized in 100 more areas globally, counting within the United States. The infection has named "SARS-CoV-2" and the infection it causes has named "corona virus infection 2019" (shortened "COVID-19"). The numerous number of patients of this flare-up at the epicenter Wuhan, Hubei Area, China had a few interface to an expansive fish and live creature showcase, for recommending the spread of animal-to-person. A short time later, a creating number of patients as far as anyone knows did not have any presentation to any animal markets, for appearing person-to-person spreading strategy. Within the Person-to-person spreading way detailed outside Hubei and counting within the United States and in countries outside China [3]. Concurring to the Institute Superiore di Sanità Italy that has had 12462 affirmed cases as of Walk 11, and 827 passing. Though it was China that has included more passing due to modern COVID-19 scene. The merciless age of those who kicked the bucket in Italy was 81 and past smokers were in numbers of more than two-third of these patients or had diabetes, cancer or cardiovascular ailments. It is hence honest to goodness that patients had principal prosperity conditions, but it to boot worth taking note that they had strongly respiratory inconvenience clutter caused by crown infection pneumonia (SARS-CoV-2). The male to female extent is $80 \%$ to $20 \%$ with a more prepared center age for ladies [4]. One of the most reasons South Korea is dealing with the corona virus episode well is that testing is broadly accessible. There are about 8,000 affirmed cases of COVID-19 in South Korea, with the primary case detailed on Jan. 20. On Friday, the nation detailed more recouped cases than new cases for the primary time [5]. Germany asserted its coronavirus-related passing inside the extremely influenced locale of Heinsberg, inside the western state of North Rhine-Westphalia. The primary passing case was an 89-year-old woman who kicked the bucket inside the town of Essen, the moment a 78-year-old man with prosperity conditions passed away in Heinsberg. Germany has so distant point by point 1,296 cases of the disease due to crown infection, concurring to figures released by the Robert Koch established (RKI) for contamination control. The RKI says the disease stances a "coordinate" danger to the general people of German [6]. Around 3,774 individuals within the U.S. have been affirmed to have the infection, in spite of the fact that numerous 
other cases may be undetected. Of those detailed cases, 69 individuals have passed away, with deaths in Virginia (1), Kansas (1), Oregon (1), South Dakota (1), Colorado (1), Louisiana (2), New Jersey (2), Florida (5), California (6), New York (6), Georgia (1), and Washington (42), The infection is significantly reshaping American life [7].

\section{METHODOLOGY OF PRECAUTIONS}

Precautions taken by the countries which have been heavily affected by Corona Virus are following-

China: China has been using aggressive quarantines which is said to be the biggest contribution for handling the outbreak of Coronavirus. Even travelers who are entering the country have to undergo a 14-day quarantine [8]. Moreover, temperature checks on passengers, limiting the crowds and intensifying the sterilization of public transports are major precautions taken by the Chinese government [9]. The government has also involved modern technologies to fight back this virus by introducing Smart Helmets, Disinfecting Robots and advanced facial recognition software's [10].

Italy: Italy's government has accelerated in taking proper actions to subdue the outbreak of the deadly Coronavirus after coming under fire for not acting faster to contain the spread [11]. As per the order of the government all shops, restaurants, and educational institutions have been closed across the country after the outbreak rose by a huge percentage [12]. People of the country are even not allowed to come out of their houses without legal permission [13]. The government is prepared to set billions of money aside to tackle Coronavirus.

Iran: Among the recorded Coronavirus cases outside of China, Iran currently has the third highest number of cases due to the negligence of the government on this matter initially [14]. Afterward, the government has ordered to shut down all the schools and universities and is disinfecting crowded spots on daily basis [15]. Iran government has released 70,000 prisoner's temporary so far in an effort to combat the spread of Coronavirus in crowded jails [16].

South Korea: Though being one of the most effected countries, South Korea is handling the Coronavirus outbreak better than other countries. From Drive-thru testing to the GPS tracking, all the precautions taken by South Korea are well organized and innovative [17]. A wide range of people are being tested everyday as the testing kits are up for grabs which has actually reduced the burden on the hospitals [18]. Moreover, the most effected step that has been taken by the government is that trying to make all information's public. Even GPS locations of people confirmed for Coronavirus are available on a mobile application so that other people can avoid the infected areas [19]

Germany: With the increasing number of cases of illness due to the novel Coronavirus, The German Government is also now doing much to protect its people [20]. The monitoring and warning mechanism for ailments has been strengthened to notify citizens of the current circumstances [21]. The German government is rigorously focused on ensuring Vaccines and other active substances to fight against Coronavirus [22]. Additionally, at airports and other transport stations emergency training exercises are regulated.

United States: Since the outbreak began in the United States, hospitals are erecting triage tents outside emergency rooms and even squeezing extra beds into all the available rooms in the hospital- government is ensuring that the hospitals are well assembled if the situation gets worse [23]. Citywide curfew has been announced to subdue the spread of Coronavirus in Hoboken, a city in New Jersey. Moreover, cities including New
York has announced a ban on gatherings of more than fifty people [24]. The first human trial of Coronavirus vaccine has started as a 43 years old woman got the first shot of that vaccine but experts maintained that to know whether this vaccine will work will take many more months [25]. In the battle of fighting against Coronavirus, every affected country and even countries prone to get an outbreak of Coronavirus are working actively with the World Health Organization (WHO) [26]. All the countries have taken some conventional precautions like putting restrictions on public gatherings and circumnavigating. Additionally, precautions like making people aware of keeping themselves sanitized, using face masks and washing hands frequently [27]. The outcomes of the immense contributions done by all countries to the safety of their citizens is showing some positive aspiration of overcoming this global crisis. A big drop in China's Coronavirus infection has already been reported [28]. The aggressive quarantine act of China appeared to be the most effective way of averting the outbreak of the novel Coronavirus. Over 69,000 people have now reported to be recovered among the 80,000 infected people in China [29]. More than 75 countries and territories worldwide this deadly virus has spread but among all the affected countries China has shown the most progress in declining the rate of new Coronavirus cases [30].The expansion of Coronavirus outbreak across the world may hit Bangladesh anytime and as Bangladesh is a heavily populated country it will take no time for the virus to become pandemic [31].Though there is no vaccine or specific treatment for this virus, few major steps can be taken by the non-affected countries like Bangladesh to prevent the highly contagious strain of the novel Corona virus. To begin with, Bangladesh government should make sure that the virus does not enter the country in the first place. The government has already put high restrictions on circumnavigating and all people are being tested whoever entering the country. Specially people coming from China are being monitored for 14 days which is the incubation period of the virus. Moreover, special wards, treatment sectors and nursing teams are getting ready in case of Bangladesh faces any sudden outbreak. Different seminars are taking place to make people aware of the deadly consequences of Coronavirus and encouraging people to maintain the basic precautions [32].

\section{OUTCOME OF COVID-19}

The number of individuals around the world known to have assaulted as a result of the widespread come to in a huge. Concurring to below table it can be known the nations which are influenced more with the novel COVID-19 out of 163 affected countries [33].

Table 1: Coronavirus COVID-19 Global Cases.

\begin{tabular}{|c|c|}
\hline Country & Cases \\
\hline China & 81050 \\
\hline Italy & 24980 \\
\hline Iran & 14991 \\
\hline South Korea & 8320 \\
\hline Spain & 9942 \\
\hline Germany & 7272 \\
\hline France & 6650 \\
\hline US & 4661 \\
\hline Switzerland & 2330 \\
\hline United Kingdom & 1553 \\
\hline
\end{tabular}




\begin{tabular}{|c|c|}
\hline Norway & 1347 \\
\hline Sweden & 1121 \\
\hline Netherlands & 1414 \\
\hline Denmark & 932 \\
\hline Japan & 833 \\
\hline Cruise Ship & 696 \\
\hline Belgium & 1058 \\
\hline Austria & 1018 \\
\hline Malaysia & 566 \\
\hline Qatar & 439 \\
\hline Singapore & 243 \\
\hline Australia & 377 \\
\hline Iraq & 133 \\
\hline India & 119 \\
\hline Canada & 439 \\
\hline
\end{tabular}

From the following pi-chart it is clearly visible that China is the most affected country from where $45 \%$ cases have been reported among all the countries across the world. In Europe, Italy has the highest number of Coronavirus affected cases and it is the 2nd highest in the world. Middle east countries are also not safe from this deadly virus as Iran has reported to have 9\% of the cases amid all the countries. Countries like France, United Kingdom, Germany also has reported high number of Corona affected cases.

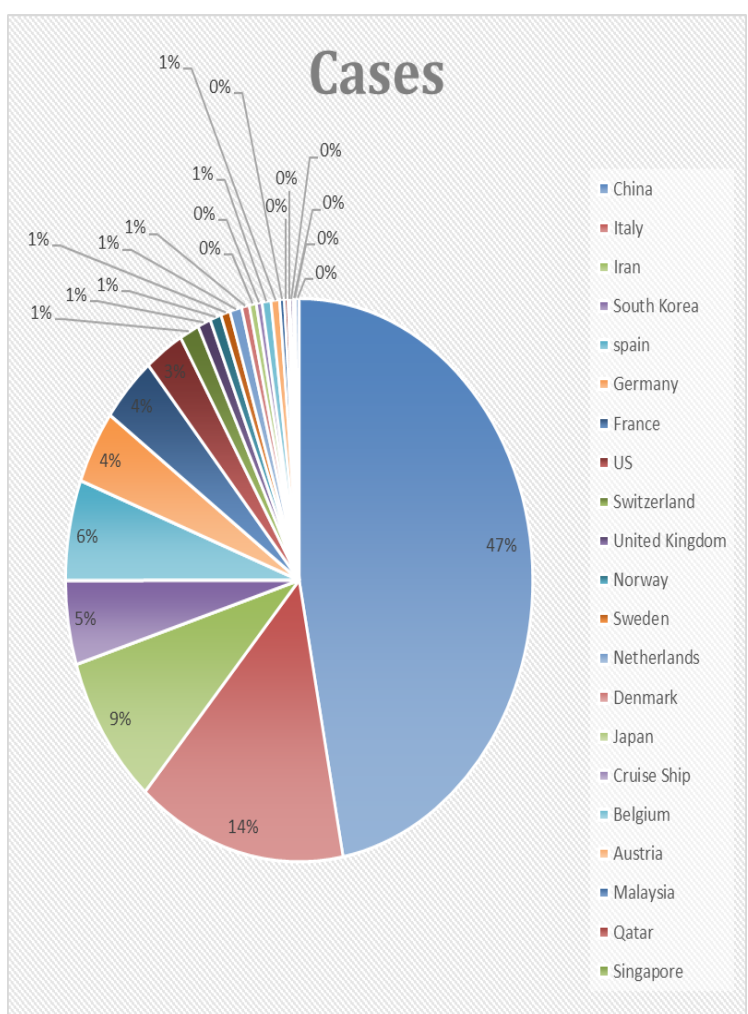

Fig 1: Estimation of the cases due to COVID-19 all over the world.
The information from the bellow table, it can be said that nations like China, Iran, South Korea, Japan, Singapore have more victory stories of recuperated cases than passing's due to the dangerous Corona virus. On the other hand, Italy, Spain and United Kingdom have nearly same number of recouped and passing cases which shows that this nation must receive better techniques to form these circumstances better. Separated from that, nations like France, Norway, Netherlands have more passing cases than recuperated cases which make these nations still within the tall threat zone.

Table 2: Records of affected countries

\begin{tabular}{|c|c|c|c|}
\hline Country/Region & Cases & Deaths & Recovered \\
\hline China & 81050 & 3230 & 68777 \\
\hline Italy & 27980 & 2158 & 2749 \\
\hline Iran & 14991 & 853 & 4996 \\
\hline South Korea & 8320 & 75 & 1137 \\
\hline Spain & 9942 & 342 & 530 \\
\hline Germany & 7272 & 17 & 67 \\
\hline France & 6650 & 148 & 12 \\
\hline US & 4661 & 85 & 17 \\
\hline Switzerland & 2330 & 19 & 4 \\
\hline United Kingdom & 1553 & 56 & 53 \\
\hline Norway & 1347 & 24 & 2 \\
\hline Sweden & 1121 & 7 & 1 \\
\hline Netherlands & 1414 & 24 & 2 \\
\hline Denmark & 932 & 4 & 1 \\
\hline Japan & 833 & 27 & 139 \\
\hline Cruise Ship & 696 & 7 & 325 \\
\hline Belgium & 1058 & 10 & 1 \\
\hline Austria & 1018 & 3 & 8 \\
\hline Malaysia & 566 & 0 & 42 \\
\hline Qatar & 439 & 0 & 4 \\
\hline
\end{tabular}




\begin{tabular}{|c|c|c|c|}
\hline Singapore & 243 & 0 & 109 \\
\hline Australia & 377 & 3 & 23 \\
\hline Iraq & 133 & 10 & 32 \\
\hline India & 119 & 2 & 13 \\
\hline Canada & 439 & 4 & 9 \\
\hline
\end{tabular}

Development Calculate is the figure by which the amount increments can be estimated by time. The condition utilized is each day's unused passing / cutting edge passing on the past day. Below chart is showing uncommonly inquisitive designs in new cases in all over the world and current energetic cases, results (death vs recovery), and numerous are getting to be dispersed inside the coming hours [33].

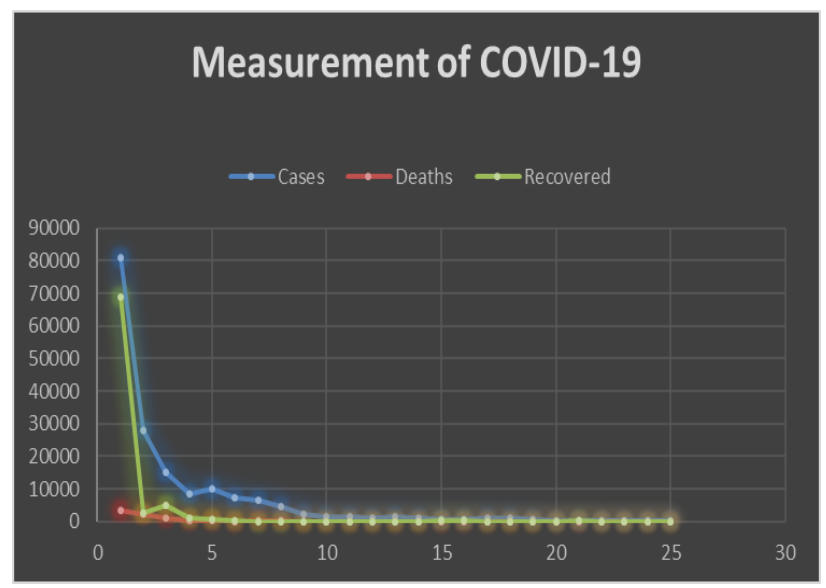

Fig 2: Measurement of COVID-19 (cases, deaths and recovered)

\section{CONCLUSION}

In the light of all the analysis and reports it can be said that the novel Corona virus may be a dangerous human-to-human transmitted infection which had basic out broke in few nations and numerous more are at the stake of being hit anytime. Numerous nations are appearing quality advance in battling against this infection by utilizing different viable safeguards, once more in numerous places the situation is even getting worse. Bangladesh in additionally attempting to get well prepared with all the essential steps as some time recently Corona infection can flare-up in South Asian nations. Though there is a high change of Coronavirus being pandemic in Bangladesh as it is a highly populated country and nearby to the affected countries like China, the temperature here is very high in summer and as this virus cannot survive in high temperature Bangladesh can be marked as situated in a partially safe zone.

\section{REFERENCES}

[1] GoogleAndroid,https://www.worldometers.info/coronaviru s/coronavirus-death-toll/?fbclid=IwAR3TNxvUFWbiz9APIGTWsbVWH6QglpLPDuHorqNIu-zay2Xd5KpTTQtGrg [Last access on 17 March. 2020].

[2] GoogleAndroid,https://www.economist.com/graphicdetail/2020/03/07/tourism-flows-and-death-rates-suggestcovid-19-is-being-under-reported [Last access on 17 March. 2020].
[3] GoogleAndroid,https://www.thelancet.com/journals/langlo/ article/PIIS2214-109X(20)30074-7/fulltext [Last access on 17 March. 2020].

[4] GoogleAndroid,https://thehill.com/changing-america/wellbeing/prevention-cures/487465-how-south-korea-ishandling-the-coronavirus [Last access on 17 March. 2020].

[5] GoogleAndroid,https://www.thelancet.com/journals/lancet/ article/PIIS0140-6736(20)30627-9/fulltext [Last access on 17 March. 2020].

[6] GoogleAndroid,https://www.bbc.com/news/world-uscanada-51835856 [Last access on 17 March. 2020].

[7] GoogleAndroid,https://www.livescience.com/coronavirusupdates-united-states.html [Last access on 17 March. 2020].

[8] GoogleAndroid,https://www.sciencemag.org/news/2020/03 /china-s-aggressive-measures-have-slowed-coronavirusthey-may-not-work-other-countries [Last access on 18 march, 2020].

[9] GoogleAndroid,https://www.bbc.com/news/world-asiachina-51718614 [Last access on 18 march, 2020].

[10] GoogleAndroid,https://www.bbc.com/news/technology51717164 [Last access on 18 march, 2020].

[11] GoogleAndroid,https://www.theguardian.com/world/2020/ mar/11/italy-faces-calls-to-close-everything-to-tacklecoronavirus [Last access on 18 march, 2020].

[12] GoogleAndroid,https://www.cnbc.com/2020/03/12/italyshops-bars-and-restaurants-ordered-to-close.html[Last access on 18 march, 2020].

[13] GoogleAndroid,https://www.aljazeera.com/news/2020/03/it aly-punishment-time-coronavirus-200312171128553.html [Last access on 18 march, 2020].

[14] GoogleAndroid,https://www.nytimes.com/2020/03/06/opini on/coronavirus-iran.html [Last access on 18 march, 2020].

[15] Google Android, https://www.bbc.com/news/av/worldmiddle-east-51830079/coronavirus-trucks-spraydisinfectant-through-tehran-s-streets [Last access on 18 march, 2020].

[16] GoogleAndroid,https://www.aljazeera.com/news/2020/03/h ard-hit-iran-frees-prisoners-coronavirus-outbreak200317110516495.html [Last access on 18 march, 2020].

[17] GoogleAndroid,https://thehill.com/changing-america/wellbeing/prevention-cures/487465-how-south-korea-ishandling-the-coronavirus [Last access on 18 march, 2020].

[18] GoogleAndroid,https://edition.cnn.com/2020/03/02/asia/cor onavirus-drive-through-south-korea-hnk-intl/index.html [Last access on 18 march, 2020].

[19] GoogleAndroid,https://www.bbc.com/news/world-asia51836898 [Last access on 18 march, 2020].

[20] GoogleAndroid,https://www.dw.com/en/coronavirus-isgermany-doing-enough-to-slow-the-outbreak/a-52770782 [Last access on 18 march, 2020].

[21] GoogleAndroid,https://www.dw.com/en/coronavirus-isgermany-doing-enough-to-slow-the-outbreak/a-52770782 [Last access on 18 march, 2020]. 
[22] GoogleAndroid,https://www.dw.com/en/coronavirusgerman-us-companies-sign-deal-to-develop-vaccine/a52802822 [Last access on 18 march, 2020].

[23] GoogleAndroid,https://www.businessinsider.com/coronavir us-us-hospitals-scramble-prepare-influx-patients-2020-3 [Last access on 18 march, 2020].

[24] GoogleAndroid,https://edition.cnn.com/2020/03/17/health/c oronavirus-vaccine-first-dose-participant/index.html [Last access on 18 march, 2020].

[25] Google Android,https://www.cnbc.com/2020/03/16/firsthuman-trial-for-coronavirus-vaccine-begins-monday-inthe-us.html [Last access on 18 march, 2020].

[26] GoogleAndroidhttps://www.who.int/countrycooperation/wh at-who-does/inter-country/en/ [Last access on $18 \mathrm{march}$, 2020].

[27] GoogleAndroid,https://www.unicef.org/bangladesh/en/stori es/coronavirus-disease-covid-19 [Last access on 18 march, 2020].
[28] GoogleAndroid,https://www.theguardian.com/world/2020/ mar/16/coronavirus-global-deaths-and-infections-overtakethose-inside-china [Last access on 18 march, 2020].

[29] GoogleAndroid,https://www.worldometers.info/coronaviru s/country/china/ [Last access on 18 march, 2020].

[30] GoogleAndroid,https://www.aljazeera.com/news/2020/03/c hina-recovered-develop-effective-covid-19-treatments200302082850237.html [Last access on 18 march, 2020].

[31] GoogleAndroid,https://www.newagebd.net/article/101292/ bangladesh-at-high-risk-of-coronavirus [Last access on 18 march, 2020].

[32] GoogleAndroid,https://www.dhakatribune.com/bangladesh/ 2020/01/29/how-prepared-is-bangladesh-to-tackle-thecoronavirus [Last access on 18 march, 2020].

[33] GoogleAndroid,https://gisanddata.maps.arcgis.com/apps/op sdashboard/index.html\#/bda7594740fd40299423467b48e9e cf6 [Last access on 17 March. 2020].

[34] GoogleAndroid,https://www.worldometers.info/coronaviru s/coronavirus-death-toll/ [Last access on 17 March. 2020]. 